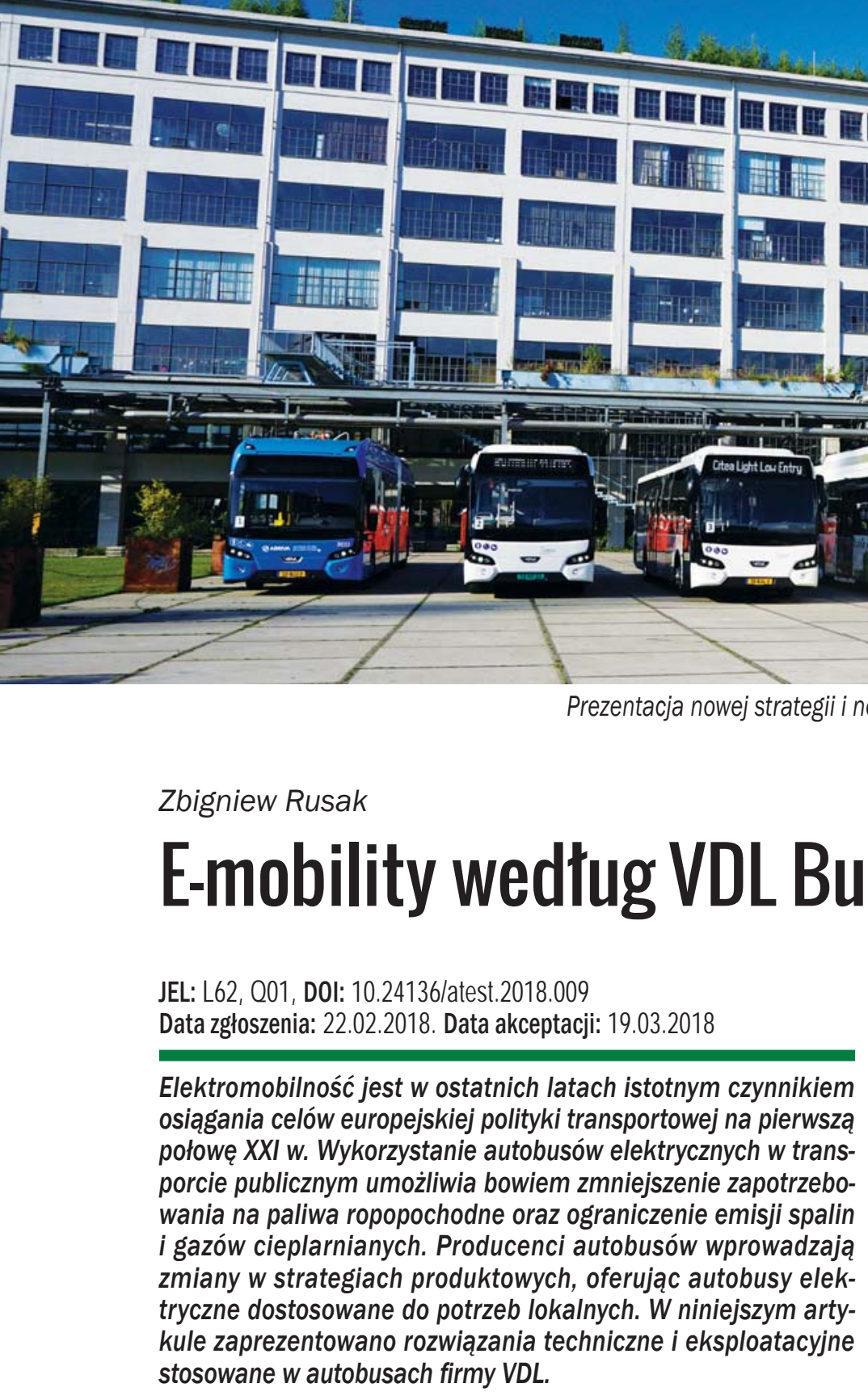

Słowa kluczowe: elektromobilność, zrównoważony rozwój, polityka transportowa.

Wzrastające zainteresowanie autobusami elektrycznymi jest wynikiem poszukiwania nowych rozwiązań w zakresie poprawy jakości powietrza w miastach, w tym ograniczania emisji $\mathrm{CO}_{2}$ w sektorze transportu. Podejmowane działania są instrumentem urzeczywistniania celów europejskiej polityki transportowej [1, 2]. Jednym z celów szczegółowych sformułowanych przez Komisję Europejską jest zmniejszenie o połowę liczby samochodów z napędem konwencjonalnym (pojazdy niehybrydowe z silnikami spalinowymi) w miastach do 2030 r. i całkowite wyeliminowanie takich pojazdów z ruchu miejskiego do 2050 r. Istotne znacznie w tym aspekcie ma możliwość wykorzystania autobusów elektrycznych [3], postrzeganych jako środek proekologiczny transportu, zapewniający konkurencyjną i zasobooszczędną mobilność w miastach [4]. Elektromobilność jest także istotnym czynnikiem pobudzania wzrostu gospodarczego dzięki rozwojowi sektora produkcyjnego nowych technologii $[5,6]$.
Gdy w 2016 r. zorganizowano w Brukseli test miejskich autobusów elektrycznych w ramach konkursu International Bus of the Year [7], wielkim nieobecnym był koncern VDL, który ma w swojej ofercie aż 6 autobusów tego typu, obejmujących pojazdy o długości od 9,9 do 18,75 m. Powodem nieobecności był duży nawał prac związanych z dostawą autobusów elektrycznych do kolejnych holenderskich miast. Od momentu światowej premiery elektrycznej Citei SLFE podczas Światowej Wystawy Transportu Publicznego w Genewie w 2013 r. VDL dostarczył ponad 200 autobusów elektrycznych. Na liście referencyjnej znajdują się nie tylko przewoźnicy komunalni, wykorzystujący w głównej mierze wsparcie lokalnych rządów i fundusze unijne, lecz również duże spółki prywatne o globalnym zasięgu, specjalizujące się w usługach komunalnych, które swoją przyszłość ściśle wiążą z rozwojem elektromobilności. Tak wysoka sprzedaż autobusów elektrycznych, jak na warunki europejskie, jest efektem nie tylko ostrej walki o zlecenia, lecz również zbudowania przez koncern całej strategii rozwoju produktów w segmencie autobusów miejskich w oparciu o analizę mobilności w europejskich obszarach aglomeracyjnych.

\section{Historia koncernu}

Grupa przemysłowa VDL powstała w 1953 r. w Einhoven. W ciągu blisko 65 lat istnienia niewielka spółka przekształciła się w duży koncern przemysłowy o zdywersyfikowanym profilu działalności, w skład którego wchodzi 90 firm rozlokowanych w 19 krajach świata. Łącznie koncern VDL zatrudnia prawie 15 tys. pracowników, którzy wypracowują 3,2 mld euro obrotu rocznie. 75\% produkcji sprzedawana jest poza Holandią i Belgią, dzięki czemu firma jest mniej wrażliwa na zmieniające się warunki ekonomiczne otoczenia. Obszar aktywności koncernu jest bardzo szeroki i poza branżą autobusową obejmuje m.in. produkcje samochodów osobowych na zamówienie innych koncernów, prefabrykowa- 


\section{producenci i poddostawcy}

ne konstrukcje stalowe, systemy automatyki przemysłowej, linie do przetwórstwa tworzyw sztucznych i obróbki powierzchniowej metali, urządzenia do przetwórstwa paliw i gazu, układy zawieszenia dla przemysłu motoryzacyjnego, systemy chłodzenia, ogrzewania i wentylacji przemysłowej, urządzenia odciągowe, systemy automatycznej detekcji i gaszenia pożarów, układy przeciwwybuchowe, urządzenia dla przemysłu rolniczego, maszyny pakujące, obudowy dachowe, a nawet łóżka do solariów. Jednak głównym sektorem działalności jest przemysł autobusowy i konstrukcji stalowych. Siłą grupy jest transfer technologii i wiedzy pomiędzy swoimi jednostkami i jak najwyższy wskaźnik wykorzystania procesów synergii.

Gdy w 1993 r. holenderski koncern VDL z siedzibą w Eindhoven, specjalizujący się w produkcji konstrukcji stalowych, rozpoczął przejmowanie kolejnych producentów autobusowych z Holandii i Belgii, wszyscy zadawali sobie pytanie, jakie cele zamierza osiągnąć nowa organizacja. Cele te wyznaczone były dość ambitnie. VDL chciał wejść do grona globalnych producentów. Pozostało tylko pytanie, jaka strategia zostanie obrana przez zarząd firmy. Czy po przejęciu wszystkich producentów słabsi zostaną zamknięci, a cały potencjał zostanie skupiony w jednej fabryce? Wejście koncernu w sektor autobusowy datuje się od 1993 r., kiedy to VDL przejął kontrolę nad DAF Bus Interantional, spółkę specjalizującą się w produkcji podwozi autobusowych. Pod koniec lat 90. Grupa VDL wchłonęła grupę Berkhof, która skupiała takich producentów autobusowych jak Berkhof, Jonckheere i Kusters. Pod koniec lat 90. w miejscowości Helmond, nieopodal granicy holendersko-niemieckiej, utworzono - wspólnie z Simac Techniek NV i Agencją Rozwoju Północnej Brabancji - spółkę APTS, która specjalizowała się w produkcji systemów BRT. W ramach systemu oferowane były niskopodłogowe autobusy przegubowe i dwuprzegubowe Phileas z napędem hybrydowym, silnikami w piastach kół, wszystkimi skrętnymi kołami oraz z systemem automatycznego prowadzenia pojazdu wykorzystującego metodę indukcji. Obecnie systemy APTS eksploatowane są w Stambule i we francuskim Douai.

W 2003 r. VDL przejął kontrolę nad znanym producentem autobusów turystycznych Bova. Wraz z macierzystą spółką przejęto także kilkanaście jej oddziałów rozproszonych po całej Europie, w tym także nad spółką Bova Polska, zlokalizowaną w Straszkowie k. Koła. Wraz z przejęciem fabryki w Valkenswaard urucho-

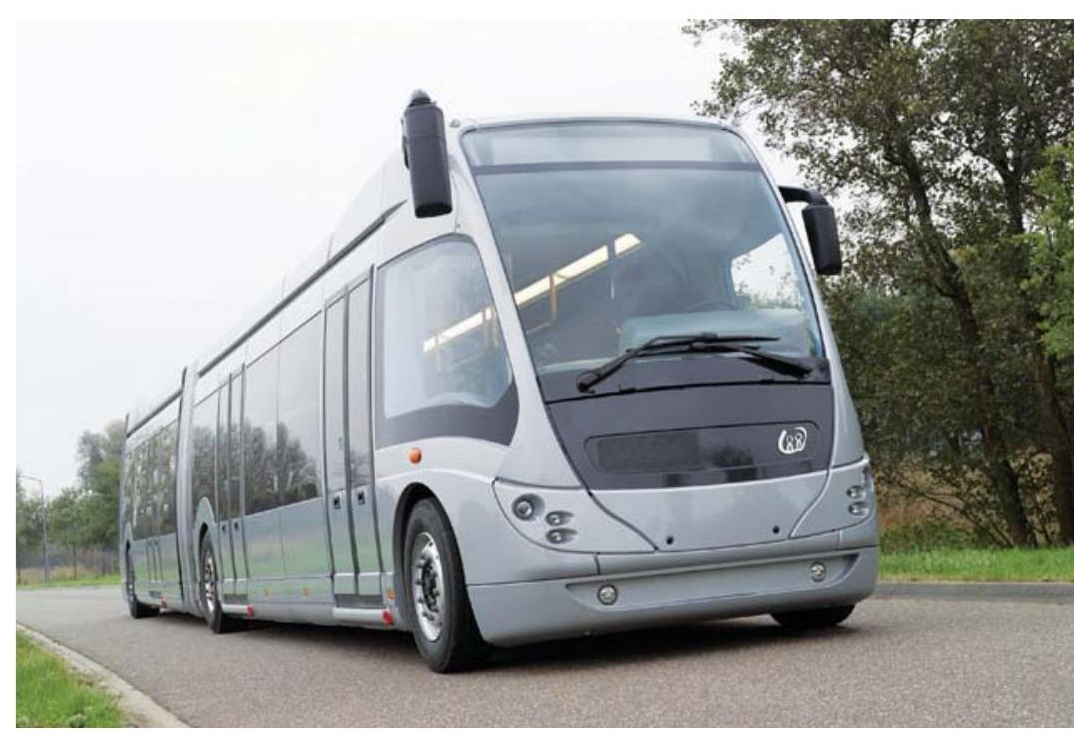

W ofercie VDL przez wiele lat bazą systemów BRT był futurystyczny autobus przegubowy VDL Phileas

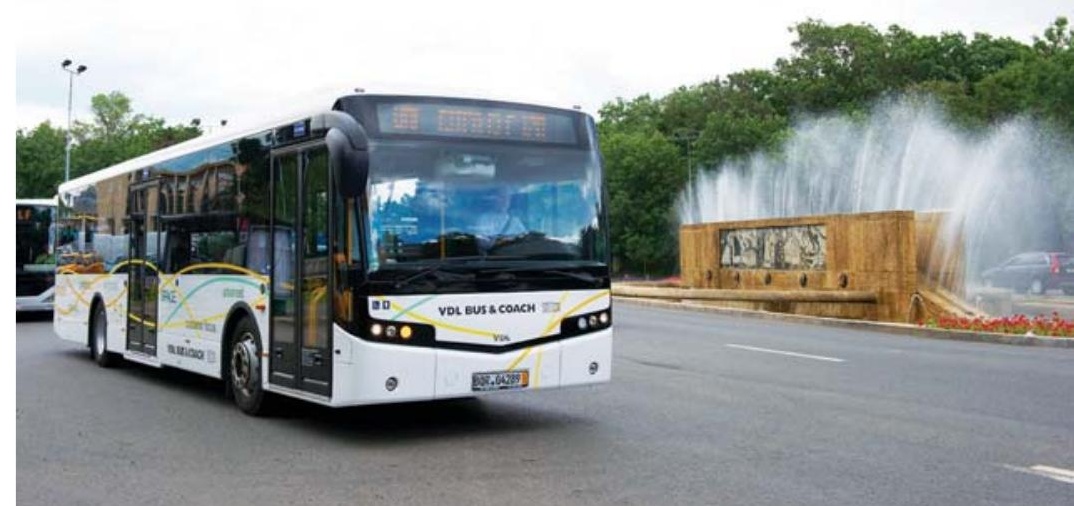

Podstawą konstrukcji autobusu elektrycznego jest konwencjonalna Citea, która w 2010 r. uzyskała tytuł Autobusu Roku

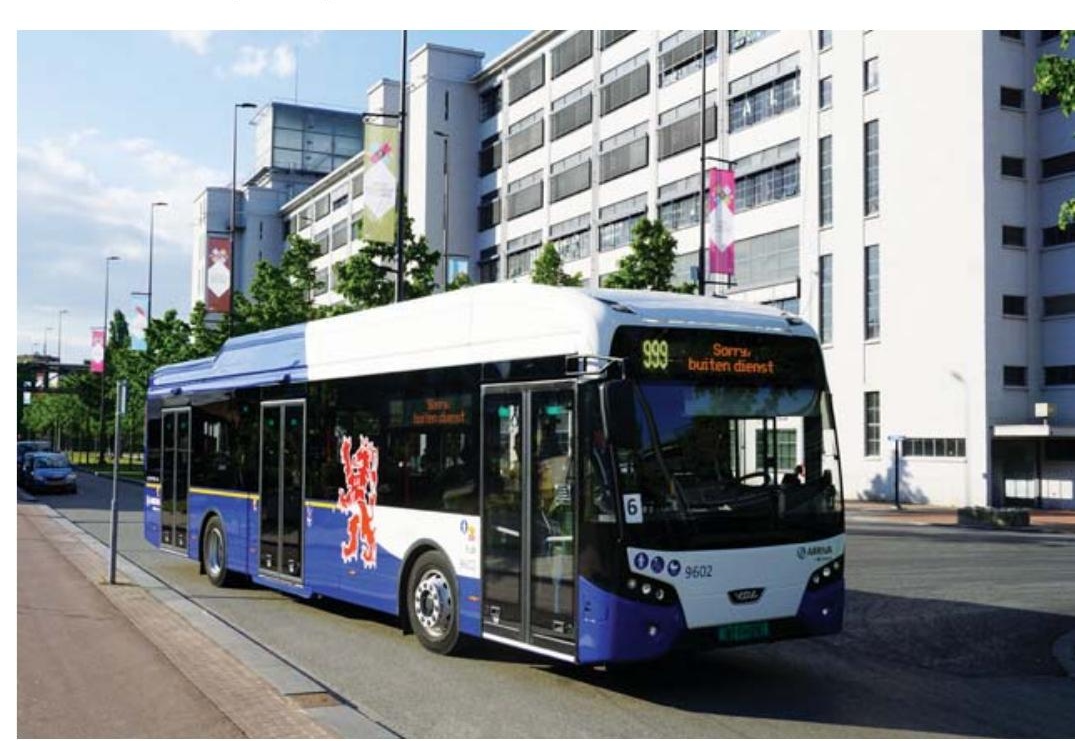

Elektryczna Citea o długości 12 m zbudowana na zamówienie globalnego przewoźnika Arriva - z lewej wnętrze komory silnikowej VDL Citea elctric 


\section{producenci i poddostawcy}

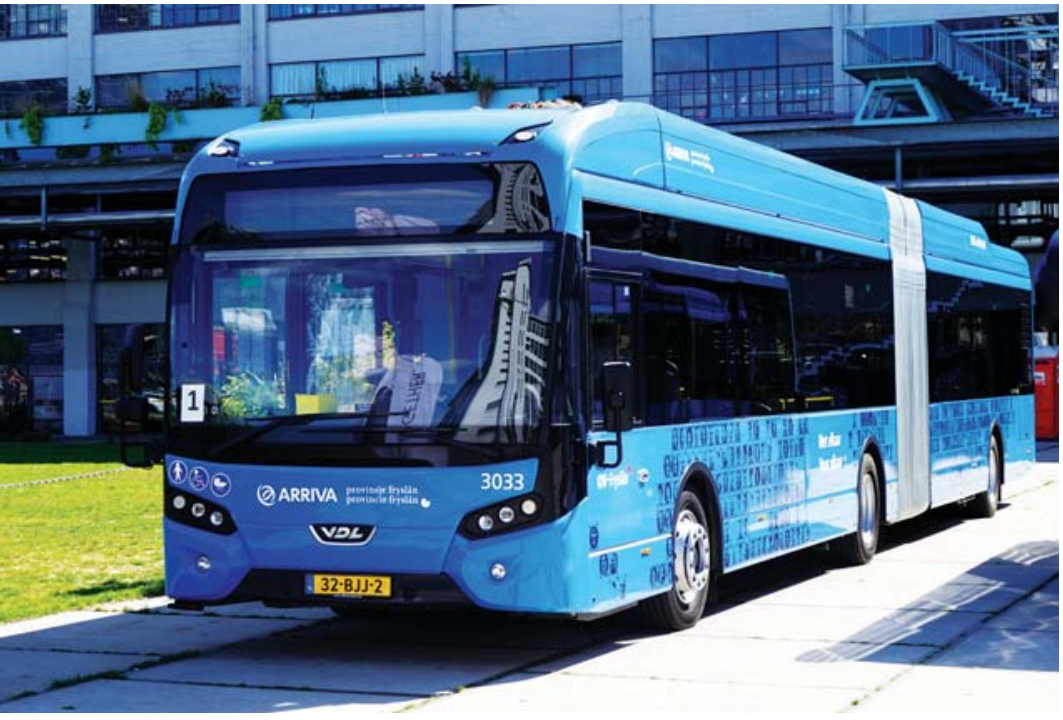

Elektryczny autobus przegubowy o długości 18,75 m, zakupiony przez firmę Arriva do obsługi systemu komunikacyjnego na Wyspach Fryzyjskich

miono produkcję autobusu klasy kombi pod nazwą Lexio, który został opracowany wspólnie przez projektantów z macierzystej firmy oraz z Berkhof Heerenveen. Rok później podjęto decyzję o rozszerzeniu oferty Bovy o autobus piętrowy Synergy, którego konstrukcja opierała się na autobusie Berkhof Axial 100 DD. Następcą tego modelu została Futura FDD2, której premiera miała miejsce podczas targów Busworld Kortrijk w 2015 r.

Przejęcie fabryki Bova zakończyło proces przejmowania producentów autobusowych. Początkowo postanowiono utrzymać cały dotychczasowy program produkcyjny kontrolowanych fabryk, które sprzedawane były pod istniejącymi markami. W 2005 r. nazwa każdej z firm została poprzedzona skrótem VDL. W 2007 r. podjęto decyzję o skonsolidowaniu działań w sektorze autobusowym pod jedną nazwą: VDL Bus \& Coach. Wynikiem tych działań było przygotowanie 2 linii produktowych: VDL Futura (autobusy turystyczne i kombi) oraz VDL Citea (autobusy miejskie i międzymiastowe bliskiego zasięgu). Uzupełnieniem oferty produkcyjnej są 3 serie minibusów: MidCity, MidBasic i MidEuro, budowanych na podwoziu Mercedes-Benz Sprinter. Przy konsolidacji poszczególnych producentów starano się w pełni wykorzystać ich potencjał

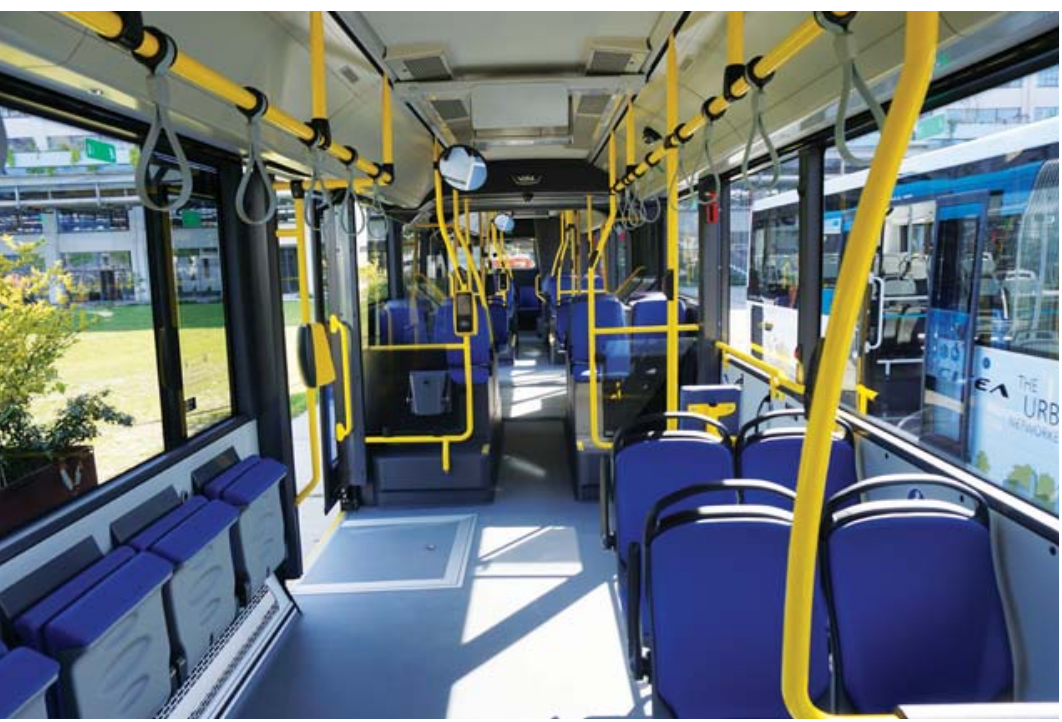

Wnętrze autobusów elektrycznych niczym nie różni się od autobusów konwencjonalnych zarówno w przestrzeni pasażerskiej, jak i na stanowisku kierowcy rynkowy. Dzięki temu VDL Groep ma bardzo szeroką ofertę autobusów, obejmującą wszystkie klasy pojemnościowe i rodzajowe. Zaawansowanie techniczne nowych konstrukcji oraz ich parametry, nastawione na maksymalne obniżenie kosztów eksploatacji zaowocowało przyznaniem nagród International Bus Of The Year 2011 dla Citei SLF i International Coach Of The Year 2012 dla Futury FHD2.

Obecnie VDL posiada 6 fabryk autobusowych. W 2016 r. wszystkie fabryki VDL Groep opuściło 1500 kompletnych autobusów miejskich, regionalnych i turystycznych. Obroty pionu autobusowego stanowiły blisko 13,6\% obrotów całego koncernu i wyniosły 437 milionów euro. Największy udział w obrotach sektora autobusowego stanowiła sprzedaż autobusów turystycznych o wartości 169 mln euro. Obroty w grupie autobusów miejskich wyniosły $151 \mathrm{mln}$ euro. W przypadku pozostałych działalności sprzedaż podwozi stanowiła 1,3\% obrotów pionu autobusowego, sprzedaż części i usług serwisowych - 14,4\%, sprzedaż autobusów używanych - $8 \%$ oraz mini- i midibusów - 3,0\%.

\section{Strategia w zakresie elektromobilności}

VDL przyjął założenie, że chociaż autobus elektryczny stanowi nowy rodzaj trakcji transportu publicznego, to jednak stanowi integralny element całego systemu komunikacyjnego. Z uwagi na rozlewanie się miast w systemie transportu publicznego możemy wyróżnić 3 podstawowe strefy jego działania. Pierwsza z nich obejmuje obszar znajdujący się w ścisłym centrum, charakteryzujący się intensywną zabudową i dużym natężeniem ruchu, który odpowiada parametrom zawartym w normie SORT-1. Średnia prędkość komunikacyjna w tej strefie waha się w granicach $10-15 \mathrm{~km} / \mathrm{h}$. To właśnie obsługa tej strefy dedykowana jest dla standardowych i wielkopojemnych autobusów elektrycznych, wspomaganych minibusami elektrycznymi MidBasic Electric oraz autobusami hybrydowymi, eksploatowanymi na liniach wylotowych z miasta. Przyjęto także założenie, że część linii o charakterze miejskim wyprowadzonych będzie do strefy drugiej oraz że tuż przed granicą strefy pierwszej rozpoczynać się będzie bieg linii, których zadaniem jest głównie obsługa strefy podmiejskiej oraz linii o charakterze regionalnym. Strefa druga - podmiejska - pozwala na uzyskiwanie wyższych prędkości komunikacyjnych: rzędu $15-20 \mathrm{~km} / \mathrm{h}$. Z uwagi na duży udział zabudowy rozproszonej obszar powinien być obsługiwany głównie autobusami średniopojemnymi z napędem elektrycznym, które także mają być wspomagane minibusami. Strefa trzecia - regionalna - charakteryzuje się korytarzową metodą obsługi komunikacyjnej, skupioną wzdłuż głównych dróg, na których możliwe jest osiągnięcie

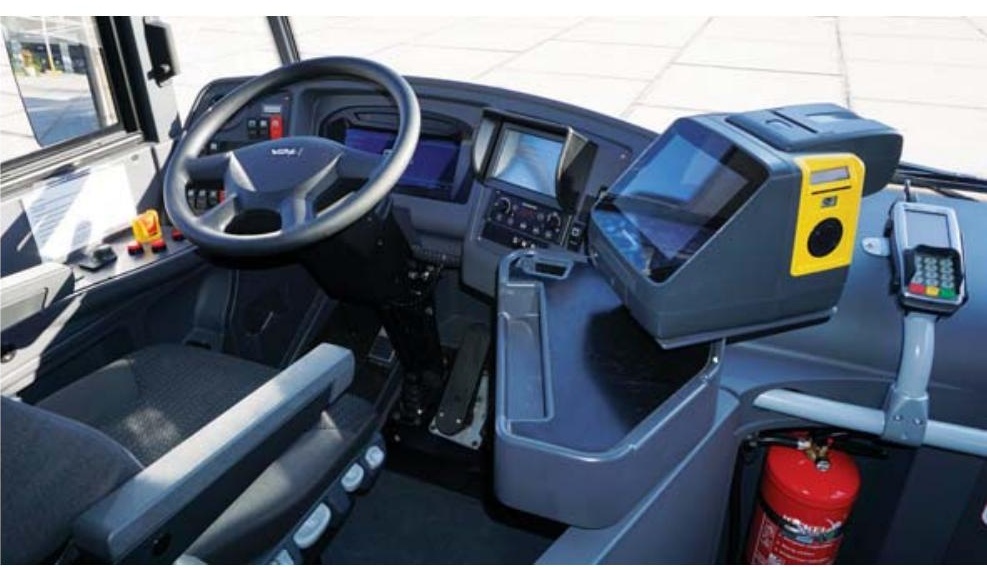




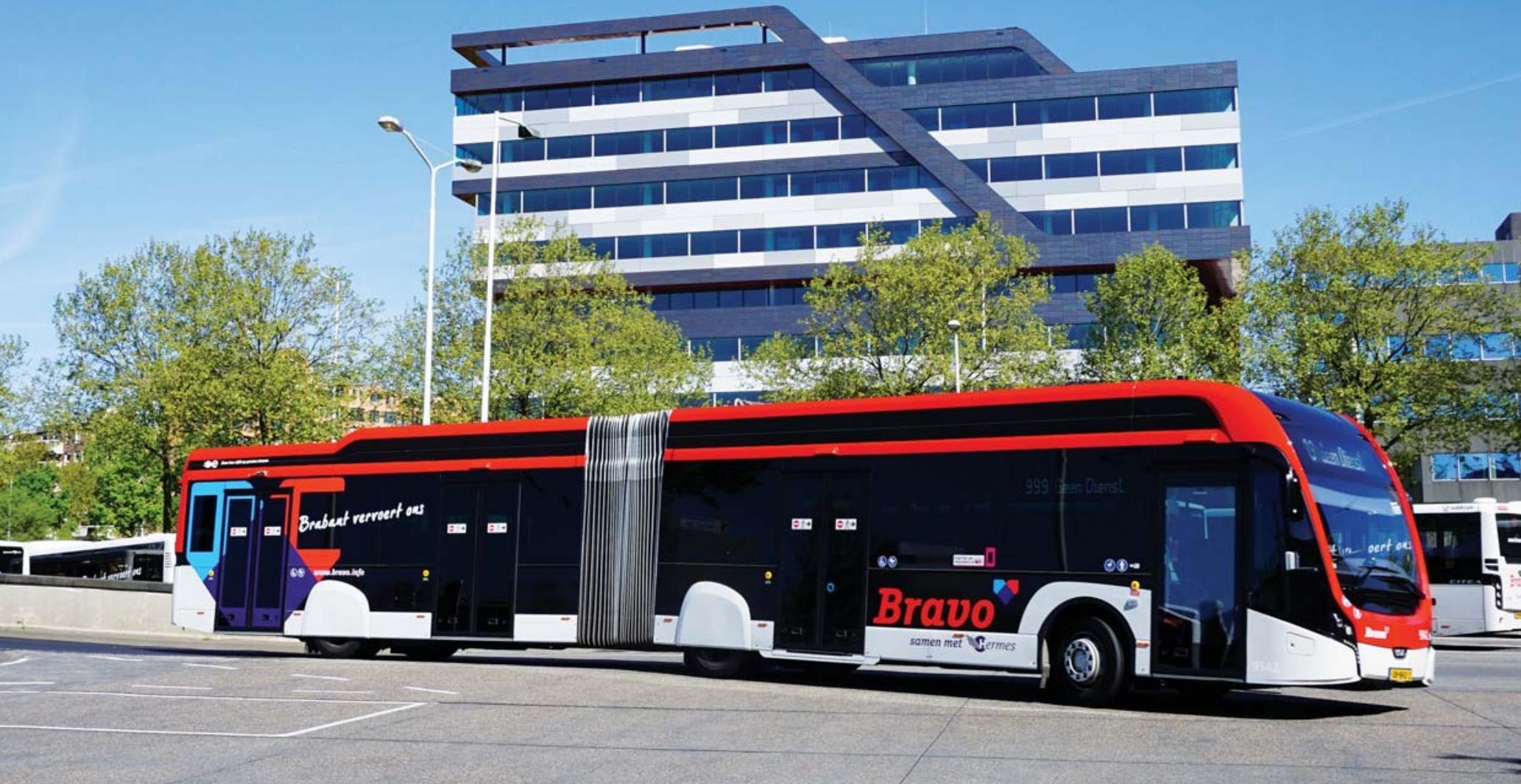

Przegubowy autobus elektryczny Clitea SLF-181 Electric w barwach firmy Hermes, obsługującej linie BRT w Eindhoven

prędkości komunikacyjnej rzędu $20-50 \mathrm{~km} / \mathrm{h}$. Ostatnia ze stref będzie obsługiwana głównie autobusami niskowejściowymi, wyposażonymi w napęd hybrydowy lub konwencjonalny z dodatkowymi systemami umożliwiającymi dalsze zmniejszenie zużycia paliwa, np. systemami start-stop.

Obecny zarząd spółki, z prezesem Henkiem Coppensem na czele, postanowił, że elektromobilność jest najważniejszą gałęzią rozwoju w sektorze autobusów miejskich. Biorąc pod uwagę dzisiejszy poziom zaawansowania technicznego, ważnym elementem będzie stworzenie partnerskich relacji z klientami - tak, aby konstrukcja nowych pojazdów była jak najlepiej dostosowana do zmieniających się potrzeb w zakresie mobilności mieszkańców. Najnowsze rozwiązania, zwłaszcza w zakresie baterii, będą szybko aplikowane w autobusach elektrycznych VDL, jednak z uwzględnieniem ostatecznej efektywności ekonomicznej i ekologicznej. Elektromobilność wymusza także, aby oferta nie ograniczała się tylko i wyłącznie do pojazdu, a obejmowała swoim zasięgiem cały system.

Przy tak zdefiniowanej strategii portfel zamówień ulega nieustannemu wzrostowi. W ostatnich 2 latach VDL podpisał następujące kontrakty na dostawę autobusów elektrycznych:

- 43 autobusy przegubowe Citea SLFA-181 dla Hermes Eindhoven, z przeznaczeniem do obsługi 5 linii BRT;

- 8 autobusów przegubowych Citea SLFA-181 dla Kolonii;

- 5 autobusów 12-metrowych SLF-120 dla Munster;

- 10 autobusów standardowych SLF-120 i 4 autobusy przegubowe SLFA-180 dla Arriva Nederland, obsługujących archipelag Wysp Zachodniofryzyjskich o powierzchni $186 \mathrm{~km}^{2}$, położnych na Morzu Północnym i zamieszkiwanych przez około 10 tys. mieszkańców;

- 12 niskowejściowych midibusów Citea LLE 99 dla Arriva Nederland, w ramach koncesji na obsługe regionu Limburgia, której częścią składową jest obsługa miasta Venlo;

- 100 autobusów przegubowych VDL Citea SLFA-181 dla Connexxion, w ramach koncesji na obsługe regionu Amstelland - Meerlanden, gdzie w głównej mierze będą eksploatowane na liniach obsługujących lotnisko Schiphol oraz na szybkich liniach autobusowych BRT zlokalizowanych na obszarze objętym koncesją;

- 10 autobusów przegubowych VDL Citea SLFA-181 dla spółki Q’Buzz, obsługującej miasto Groningen;

- 10 niskowejściowych midibusów dla LLE 99 dla Luksemburga. Dzięki tym zrealizowanym już kontraktom VDL stał się europejskim liderem w produkcji autobusów elektrycznych, kontrolując $31,2 \%$ rynku na naszym kontynencie.

\section{Autobusy elektryczne Citea}

Światowa premiera autobusu elektrycznego Citea SLF electric miała miejsce podczas Kongresu UITP w Genewie. Jego konstrukcja bazuje na typowym egzemplarzu 12-metrowej Citei SLF i charakteryzuje się bardzo wysokim stopniem unifikacji komponentów. VDL Citea to rodzina niskopodłogowych (SLF) i niskowejściowych (LLE) autobusów miejskich i lokalnych o długości od 9,9 do $18,75 \mathrm{~m}$. Od 2007 r. do rąk klientów trafiło łącznie 4,5 tys. pojazdów tego typu. Modułowa konstrukcja bazowej Citei została tak przygotowana, aby bez wprowadzania żadnych istotnych modyfikacji pojazd mógłby być oferowany na wszystkich rynkach europejskich. Główny nacisk przy opracowywaniu nowej konstrukcji położono na niskie koszty eksploatacji, niską masę, wysoką niezawodność, łatwość obsługi i naprawy oraz szerokie możliwości aranżacji wnętrza. Dzięki modułowości umożliwiono szybkie tworzenie kolejnych wersji nadwoziowych, a wnętrze autobusu tak zaprojektowano, aby autobus można było z powodzeniem wykorzystywać jako autobus miejski, podmiejski lub regionalny. W autobusie zastosowano sandwichową technologię budowy dachu i ścian bocznych, co ma istotny wpływ na niską masę własną. Citea to jeden z najlżejszych z autobusów miejskich oferowanych w Europie. Masa własna w wersji 12-metrowej, w zależności od wyposażenia, wynosi około 10600 kg. Niska masa ma wpływ na dużą pojemność autobusu i niskie zużycie paliwa. Mimo dużych powierzchni szklanych oraz zastosowania profili o mniejszym przekroju nadwozie w pełni spełnia wymagania normy ECE-R66.02. To właśnie ten model został bazą do opracowania pierwszego autobusu VDL z napędem elektrycznym. 


\section{producenci i poddostawcy}

pod przystanek. Zmianie uległa także ściana tylna, zdominowana przez dużą przyciemnianą szybę, która została połączona optycznie poprzez polakierowaną na czarno tylną pokrywę osłony dachowej. Oryginalny design nowego nadwozia został nagrodzony w 2017 r. prestiżową nagrodą red-dot.

Aby zapewnić odpowiednią wysokość przejścia przy tak mocno pochylonej przedniej szybie, na zwisie przednim zastosowano drzwi jednoskrzydłowe. Mimo tego ich szerokość jest bardzo duża i wynosi $1000 \mathrm{~mm}$.

Zachowanie odpowiedniej prędkości wymiany pasażerów osiągnięto poprzez wprowadzenie pozostałych drzwi o szerokości czynnej 1350 mm. Citea SLFA electric o długości 18,15 m przystosowana jest do przewozu maksymalnie 140 pasażerów, w tym 37 na miejscach siedzących. Wnętrze nowego autobusu niewiele odbiega od seryjnego autobusu z napędem konwencjonalnym. Mała liczba podestów powoduje, że aż 19 miejsc jest dostępnych bezpośrednio z poziomu niskiej podłogi. Tuż za przednim nadkolem zabudowano stanowisko do mocowania wózków inwalidzkich, zgodnych ze standardem EU 2001/85.

Autobus przegubowy napędzany jest pojedynczym silnikiem Siemens 1DB2022 o mocy ciągłej 210 kW. Dzięki systemowi doładowywania baterii na końcówkach, w przypadku autobusu dla Kolonii, pojemność baterii Aksol Li-Ion NMC ograniczono do 122 kWh. Jednak większość sprzedanych autobusów przegubowych została wyposażona w baterie o pojemności 180 kWh. Zastosowanie baterii o większej pojemności powoduje zmniejszenie maksymalnej liczby przewożonych pasażerów o ok. 7\% - ze 140 do 130.

Na dachu, nad środkową osią, zamontowano pantograf firmy Schunk o maksymalnej mocy ładowania do $250 \mathrm{~kW}$. Obok nadwozia o długości 18,15 m elektryczne autobusy przegubowe oferowane są także z klasyczną ścianą czołową z nadwoziem o długości 18 m i 18,75 m. W tym przypadku przewoźnicy mogą wybrać także wersje z dwuskrzydłowymi drzwiami na zwisie przednim.

Ostatnim z wprowadzonych do produkcji przez VDL autobusów elektrycznych był niskowejściowy midibus o długości 9,95 m, szerokości 2,5 m i pojemności 60 pasażerów (w tym 28 na miejscach siedzących). Pierwszych 12 egzemplarzy tego autobusu zakupiła Arriva Nederland na potrzeby obsługi komunikacji miejskiej w Venlo przy granicy z Niemcami. Konstrukcję tego pojazdu oparto na konwencjonalnym midibusie LLE-99. Z uwagi na fakt, iż midibus ten pozbawiony jest charakterystycznej wieży silnika, wszystkie komponenty elektrycznego układu napędowego zamontowano w podpodłogowej komorze silnikowej na zwisie tylnym oraz w specjalnej szafie, usytuowanej ponad lewym, przednim nadkolem. Tym samym, tak jak w przypadku autobusów 12- i 18-metrowych, nie utracono nic z tak cennej powierzchni użytkowej przedziału pasażerskiego. W porównaniu z wersją napędzaną silnikiem diesla, elektryczny midibus charakteryzuje się mniejszą o 16 osób pojemnością. W układzie napędowym zastosowano ten sam silnik co w autobusie 12-metrowym. Biorąc pod uwagę, że dopuszczalna masa całkowita autobusu 10-metrowego jest o $3600 \mathrm{~kg}$ niższa niż w autobusie 12-metrowym, parametry ruchowe tego "malucha” są rewelacyjne. Obok wysokiej dynamiki, autobus charakteryzuję się dużą zwrotnością. Jego zewnętrzna - obrysowa - średnica zawracania wynosi jedynie $16750 \mathrm{~mm}$. Jest to 4,4 m mniej niż w przypadku autobusu 12-metrowego. Z uwagi na fakt, że autobusy tego typu zostały przeznaczone do obsługi linii przebiegającej przez historyczne centrum miasta, w którym występują ograniczone możliwości bu- dowy infrastruktury ładowania, w autobusie zamontowano duże baterie o pojemności 180 kWh. Tak jak w przypadku większych modeli, baterie ładowane są na terenie zajezdni za pomocą złącza plug-in o mocy 50kW lub za pomocą pantografu umieszczonego ponad tylną osią (o mocy $300 \mathrm{~kW}$ ).

Wszystkie wersje Citea Electric charakteryzują się szerokimi możliwościami aranżowania wnętrza, tak aby optymalnie dostosować je do potrzeb konkretnego przewoźnika. Zostało to osiągnięte dzięki zoptymalizowaniu liczby podestów. Dodatkowo zastosowanie foteli typu canti lever z mocowaniem do ściany bocznej autobusu znacznie ułatwia sprzątanie wnętrza pojazdu.

\section{Autobusy VDL Citea z napędem konwencjonalnym o obniżonej emisji spalin}

Istotnym uzupełnieniem strategii elektromobilności są autobusy konwencjonalne, charakteryzujące się możliwe jak najniższym zużyciem paliwa, co ma bezpośredni wpływ na ograniczenie emisji $\mathrm{CO}_{2}$. Bardzo ważnym elementem oferty VDL są ultralekkie autobusy niskowejściowe serii LLE z nadwoziami o długości 9,9 m, 10,7 m, 12,0 m i 12,67 m. Ich masa własna - w zależności od wersji - waha się od 8700 kg do 9300 kg. W 2017 r. w autobusach tych, napędzanych silnikiem Cummins ISBe6,7 o mocy 187 kW (255 KM), charakteryzujących się bardzo niskim przebiegowym zużyciem paliwa, wprowadzono kolejne modyfikacje, w efekcie których osiągnięto dalsze obniżenie zużycia paliwa od około 5 do 8\%. Podstawową modyfikacją było wprowadzenie systemu start-stop, automatycznie wyłączającego silnik w 3 s od momentu zatrzymania autobusu na przystanku lub przed skrzyżowaniem. Ponowne uruchomienie silnika trwa niecałą sekundę od momentu naciśnięcia pedału gazu. Kolejna nową funkcjonalnością Citei jest układ rekuperacji energii hamowania, co wymagało zastosowania nowych alternatorów, kompresora i baterii, w których przechowywana jest energia wytworzona podczas hamowania.

Wraz z pracami nad optymalizacją konstrukcji, pod kątem spełnienia wymagań normy ECE-R66.02, ponownie zmniejszono mase pojazdu, w wyniku zastosowania technologii sandwichowej w obszarze niskiej podłogi. Podczas prezentacji autobusów

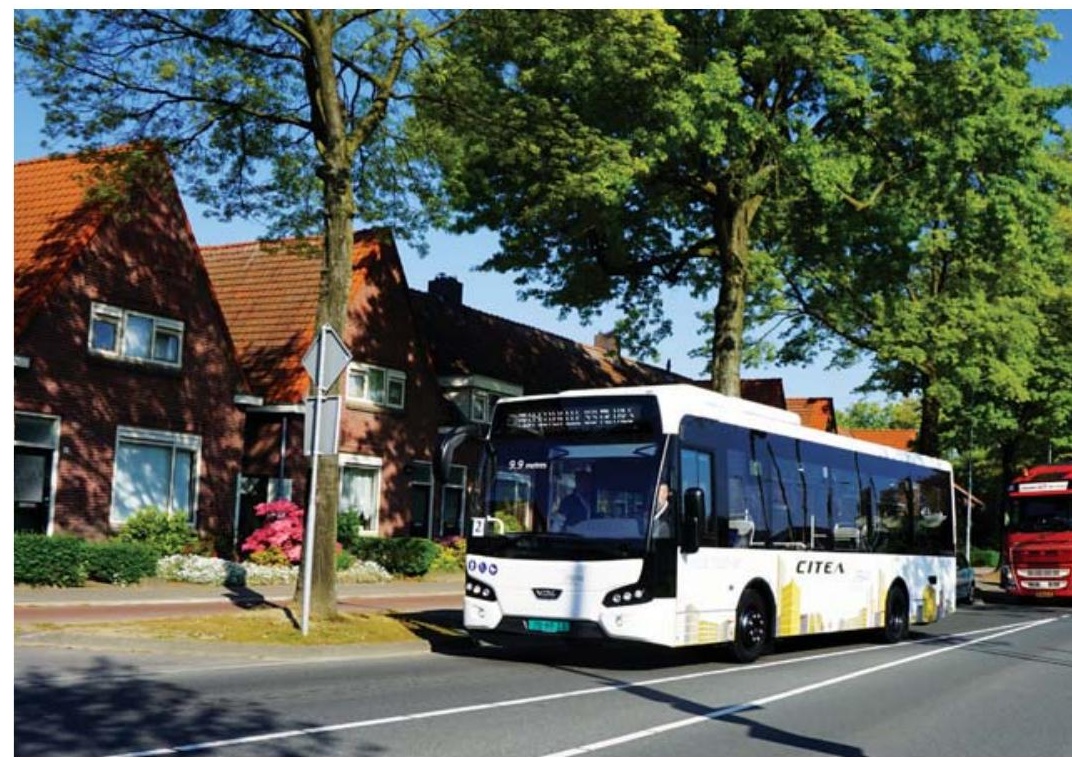

LLE-99, zarówno w wersji konwencjonalnej, jak i elektrycznej, z powodzeniem nadaje się do obsługi osiedli mieszkaniowych o zwartej zabudowie i wąskich uliczkach 
elektrycznych w Eindhoven pokazano także 2 autobusy nowej generacji:

- Citea LLE-99/255 o pojemności 78 pasażerów;

- Citea LLE-120/255 o pojemności 85 pasażerów.

Z uwagi na fakt, że autobusy te adresowane są w pierwszym rzędzie do obsługi linii wybiegowych, charakteryzujących się dużą długością, zastosowano w nich dużą liczbę miejsc siedzących: w autobusie klasy midi - 29 (w tym 8 bezpośrednio z niskiej podłogi), a w autobusie klasy maxi - 41 (w tym 12 bezpośrednio z niskiej podłogi).

\section{Podsumowanie}

Patrząc na minione 25 lat, widzimy, że koncern VDL wykonał olbrzymi krok naprzód. Początkowo wydawało się, że kierownictwo koncernu będzie utrzymywać działanie nowej organizacji jako zlepka niezależnych producentów o zasięgu lokalnym, gdzie procesy synergii wykorzystywane będą jedynie w logistyce i pracach projektowych. Mimo wysokiej pozycji, jaką osiągnęła na międzynarodowym rynku Bova, postanowiono, że nadszedł już czas wykreowania jednej wspólnej marki. Nowe produkty, w połączeniu ze strategią MOVE.TOGETHER, pozwoliły na osiągnięcie dalekosiężnych celów. Kolejny silny producent autobusowy, działający w skali globalnej, sprawił, że znacznie zwiększyła się konkurencyjność rynku autobusowego. Ma to bezpośrednie przełożenia na jakość oferowanych autobusów, ich cenę i jakość sieci serwisowej. Ciągła współpraca z klientami powoduje, że VDL nie chce ograniczać się jedynie do oferowania kompletnych autobusów, lecz zamierza oferować całe systemy transportowe, w których autobusy z napędem elektrycznym będą stanowić jego istotny element.

\section{Bibliografia:}

1. Biała Księga Plan utworzenia jednolitego europejskiego obszaru transportu - dążenie do osiągnięcia konkurencyjnego i zasobooszczędnego systemu transportu, KOM (2011) 144.
2. Dyr T., Europejska polityka transportowa na pierwsza połowę XXI wieku, „Autobusy - Technika, Eksploatacja, Systemy Transportowe" 2011, nr 10.

3. Dyr T., Europejska strategia w zakresie paliw alternatywnych „Autobusy - Technika, Eksploatacja, Systemy Transportowe” 2013, nr 11.

4. Dyr T., Konkurencyjna i zasobooszczędna mobilność w miastach, „Autobusy - Technika, Eksploatacja, Systemy Transportowe" 2015, nr 1-2.

5. Kozłowska M., Abramowicz A., Transport pasażerski w Strategii na rzecz odpowiedzialnego rozwoju, „Autobusy - Technika, Eksploatacja, Systemy Transportowe" 2017, nr 7-8.

6. Molecki A., Elektromobilność a komunikacja publiczna, „Autobusy - Technika, Eksploatacja, Systemy Transportowe” 2017, nr 9.

7. Rusak Z., Bus Euro Test 2016 w Brukseli, czyli „Umarł Diesel. Niech żyje elektryczność”, „Autobusy - Technika, Eksploatacja, Systemy Transportowe” 2016, nr 6.

\section{E-mobility according to VDL Bus and Coach}

In the recent years electromobility is an important factor of achieving goals of European transport policy for the first half of the 21st century. Using electric buses in the public transport allows to reduce the use of petroleum-derived fuels and emission of exhaust and greenhouse gases. Bus manufacturers are introducing changes to products strategies by offering electric buses, adapted to local needs. This article presents technical and operating solutions used in VDL buses.

Keywords: electromobility, sustainable development, transport policy.

Autor:

mgr inż. Zbigniew Rusak - Instytut Naukowo-Wydawniczy „Spatium” w Radomiu

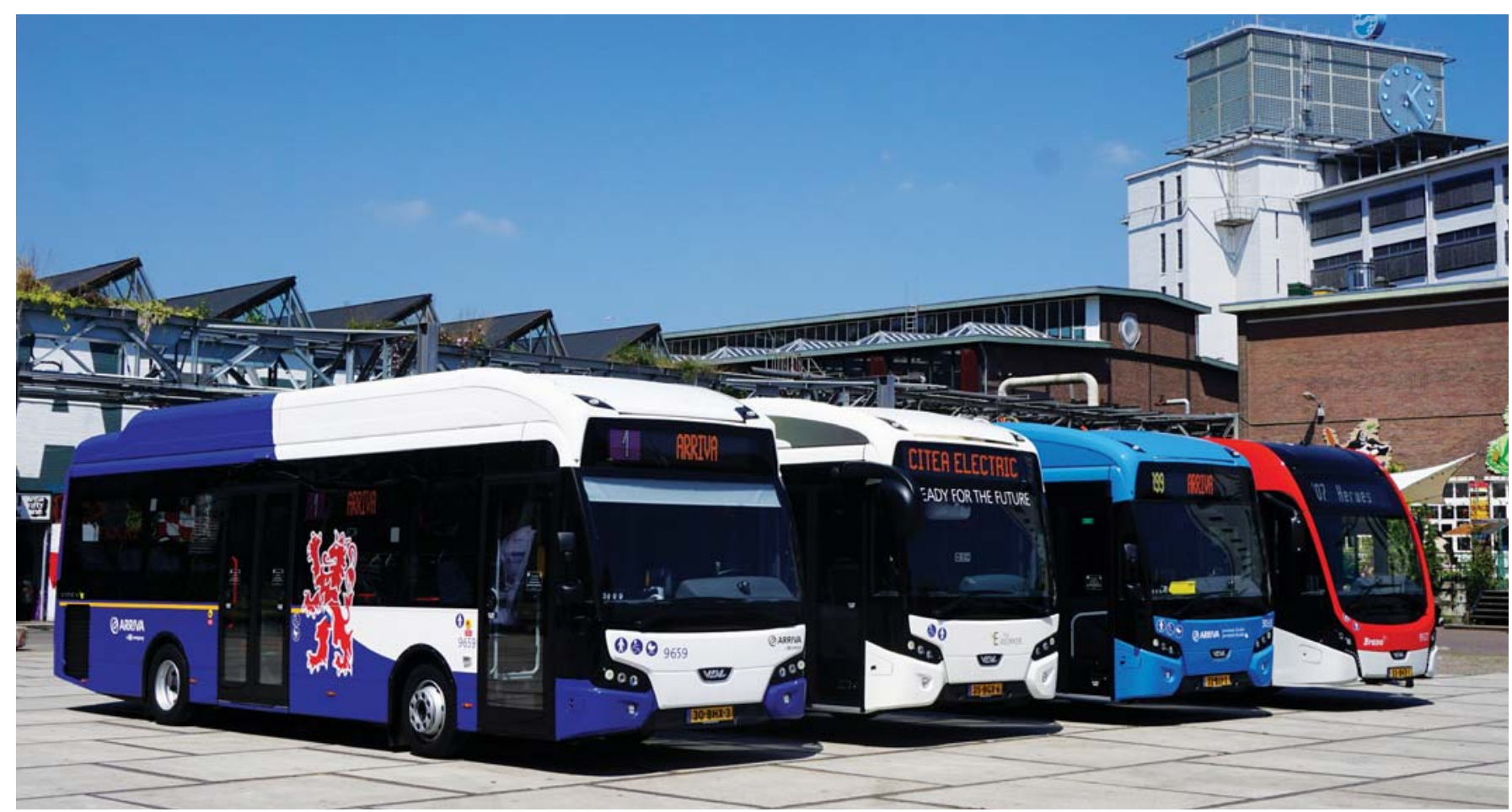

Nowa gama produktów koncernu VDL 